\title{
Profiles: Benjamin Lebwohl, MD, MS
}

\section{Benjamin Lebwohl ${ }^{1}$}

Published online: 26 February 2018

(c) Springer Science+Business Media, LLC, part of Springer Nature 2018
I have been fortunate to be the recipient of superb mentorship for as long as I can remember. My father, Oscar Lebwohl, is a gastroenterologist who took home with him only the good aspects of medicine as I was growing up: stories about rewarding patient encounters, anecdotes about his interesting colleagues, and the occasional gift basket from a grateful patient. The New England Journal of Medicine was delivered to our home each week; in high school, I would usually check out the regular "Images in Clinical Medicine" feature and would often scan the article titles, occasionally understanding at least a few words of each. This always kept medicine in the forefront of my mind as a career choice.

But if I inherited an interest in medicine from my father, I inherited a double dose of passion for music from both my father and my mother, Vida Lebwohl. They had met at a summer program at the Juilliard School that was geared to high school students, as he (a violinist) and she (a pianist) developed their technical skills in musical performance and went on to marry upon graduating college. I grew up playing the cello and became infatuated with the symphonic repertoire, and then even more obsessed with opera. As I faced the prospect of being able to study any courses at all when starting college, I wanted to make music my primary focus, while laying out a long-term plan for medical school by taking the required courses concurrently.

On the first day of class, I decided to major in music. On that day, Professor John Stewart, teaching introductory music theory, sat at the piano and played three chord cadences, telling us that two of the three were regularly used by Bach in his $>350$ chorales but that one of the three never appeared. He asked us to guess which of the three was considered sonically taboo by Bach, but I was embarrassed to find that I could not hear the difference among the chords! I

Benjamin Lebwohl

BL114@columbia.edu

1 Department of Medicine, Celiac Disease Center, Columbia University Medical Center, 180 Fort Washington Avenue, Suite 936, New York, NY 10032, USA was intent on developing my ear so that I could distinguish subtle sounds and to learn how to analyze great music.

As I continued my studies, I took several classes with Professor Lewis Lockwood who would be my mentor for years extending far beyond my time in college. As a teacher, he specialized in "deep dive" explorations of a subject, teaching a semester-long seminar devoted entirely to Beethoven's Ninth Symphony. (When students would ask him, "You're spending the whole semester on Beethoven's Ninth?" he would respond wryly, "Yes, only one semester!") Professor Lockwood exemplified a life of scholarship: he embraced his teaching duties as a serious charge, engaging intensely with his students and considering teaching and learning a twoway process. His research on Beethoven's sketchbooks left a mark on the field of musicology, and his biography of that composer, aimed for mass audiences and published in 2003, remains the ultimate synthesis of history, musical analysis, and psychological portrait [1]. Although I had started medical school by the time that the book was published, reading this magnificent book over the course of a year allowed me to continue my study of Beethoven and to keep in touch with Professor Lockwood. Years later, when, as a Chief Medical Resident, I was charged with identifying cases for ClinicalPathologic Correlation conferences, I chose Beethoven to be my subject for one conference; I reconnected with Professor Lockwood, who offered feedback on my presentation of Beethoven's illnesses and the findings of the composer's autopsy. (Notable findings include a cirrhotic liver, turbid ascites, and signs of chronic pancreatitis.)

During my years as a medical student at Columbia College of Physicians and Surgeons, I was lucky to meet Peter Green, who is to celiac disease what Lewis Lockwood is to Beethoven. Dr. Green introduced me to the opportunities and excitement inherent to clinical research in general, and celiac disease in particular. I stayed on as a resident in internal medicine at New York Presbyterian/Columbia University Medical Center, and on my first month on the inpatient service my supervising attending was Alfred Neugut, a renowned population scientist with expertise in gastrointestinal (GI) cancer and methodologic skill in the construction 
of analyses of existing data sets to test clever hypotheses via observational studies. As we got to know each other and I shared with $\mathrm{Al}$ my growing interest in gastroenterology, he encouraged me to obtain training in population science and research methods, which I did via a Masters degree from Columbia's Mailman School of Public Health. As I was completing my GI fellowship, also at Columbia, I continued to benefit from the co-mentorship of Peter and $\mathrm{Al}$, individuals with complementary skillsets but a shared enthusiasm for advancing both medical science and supporting the next generation of investigators with their time and encouragement.

I am often asked by patients why I majored in music or why I chose a career in medicine (or both). I joke that music is easier to do "on the side" than colonoscopy! But ultimately, the answer comes down to having more than one passion and learning to be comfortable in two worlds. It is particularly rewarding to engage in activities that involve both fields simultaneously, such as preparing a presentation on Beethoven's illnesses, playing in the cello section of the Columbia University Medical Center Symphony Orchestra, or hunting for adenomas during colonoscopy while Don Giovanni plays in the endoscopy room. But it can be completely fulfilling to be involved in one pursuit or the other, with the knowledge that I have had the good fortune to have mentors in both worlds who have helped me along the way.

\section{Reference}

1. Lockwood LH. Beethoven: The Music and the Life. New York: W.W. Norton; 2003. 